\title{
SOIL STABILISATION USING GLASS POWDER
}

\author{
Mahdi Keramatikerman \\ Engineer, Arup Australia, 61-73 Sturt Street, \\ Suncorp Tower, Townsville QLD 4810, Australia \\ Amin Chegenizadeh \\ Senior Lecturer, Department of Civil Engineering,
} Curtin University of Technology, Kent Street, Bentley, Perth, Western Australia 6102, Australia

Hamid Nikraz

Professor, Department of Civil Engineering, Curtin University of Technology, Kent Street, Bentley, Perth, Western Australia 6102, Australia.

\begin{abstract}
Stabilisation techniques are used around the world to increase shear or compressive strength and settlement characteristic of soils. This study uses 3 percentages of glass powder (i.e. $2 \%, 4 \%, 6 \%$ ) into soil and investigates the effect of glass powder into unconfined compressive strength (UCS) values. The results showed that application of glass powder is effective to improve UCS behvaiour of soil
\end{abstract}

\section{Keywords - UCS, Glass powder, stabilisation}

\section{INTRODUCTION}

Soil stabilisation using additives is an area of study in geotechnical engineering that improve mechanical behvaiour of the soil [1-8]. Sand is one of the most applicable types of soil that is used in construction and infrastructure industries [9-13]. There has been many research in soil stabilisation using different additives. For instance, there has been studies on fibre reinforced soil [14-21], slag stabilized soil [22-25], flyash stabilized soils [26-30], and glass [31-45] their application in different geotechnical structures. This study will investigate how the glass can be effective in improving of strength of specimens.

\section{MATRIALS}

The used materials were sand which is known as yellow sand with specific gravity (Gs) of 2.65. The used glass powder had a mean size of glass powder was $0.5 \mathrm{~mm}$. Also, ordinary Portland cement type II was utilized in this study as a cementitious agent.

\section{COMPACTION TESTING}

In order to get the UCS samples, the first stage was to run the compaction tests. The following results were derived. Fig. 1 shows the results of compaction testing that leads to extracting optimum moisture content (OMC) and maximum dry density (MDD) calculations.

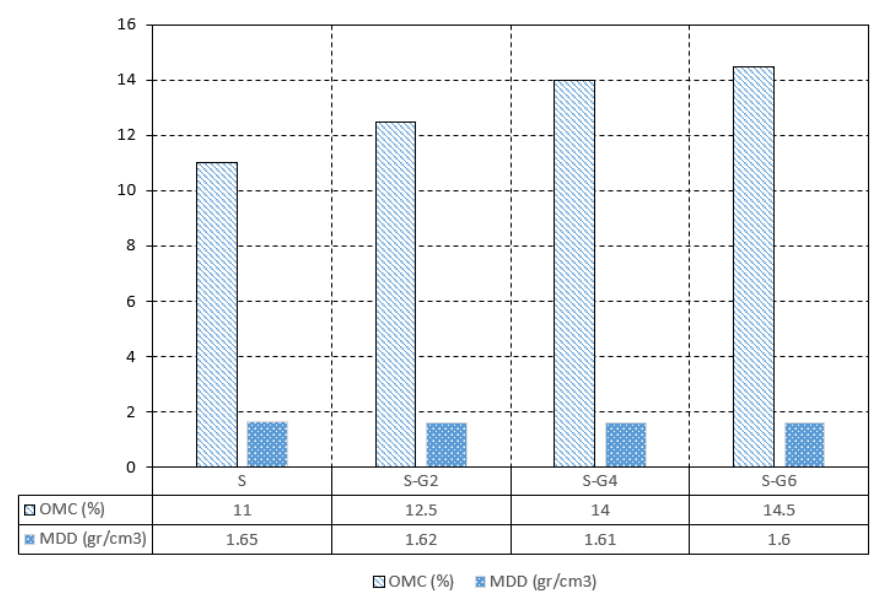

Fig. 1. Effect of glass powder addition on OMC and MDD

IV.

UCS

The UCS tests was conducted on the specimens and the following results were derived after 3, 7, 14, and 28 days curing time as shown in Fig. 2, Fig. 3, Fig. 4, and Fig. 5 respectively.

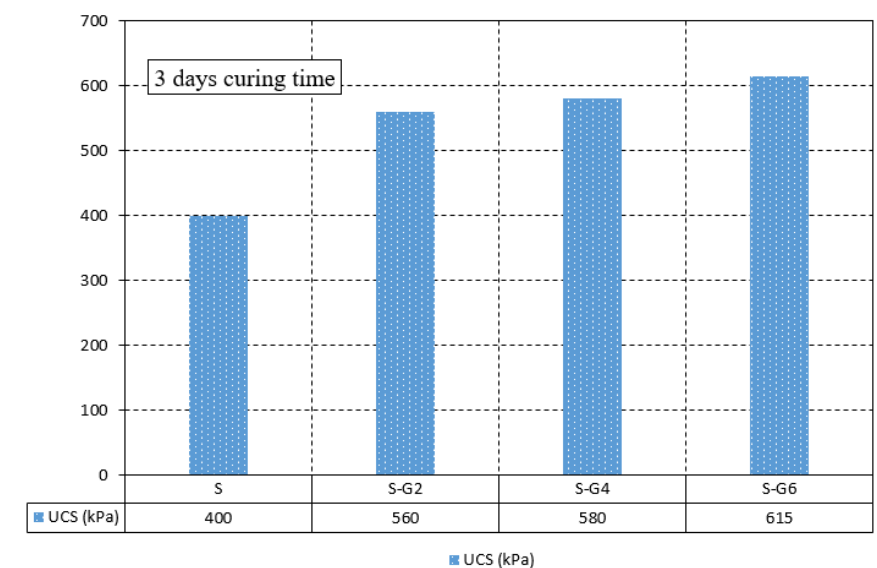




\section{International Journal of Engineering Applied Sciences and Technology, 2020 \\ Vol. 4, Issue 11, ISSN No. 2455-2143, Pages 339-342 \\ Published Online March 2020 in IJEAST (http://www.ijeast.com)}

Fig. 2. Effect of glass powder addition on UCS value after 3days curing time.

As can be seen the trend shows increment by increasing glass percentages for 3 days curing time.

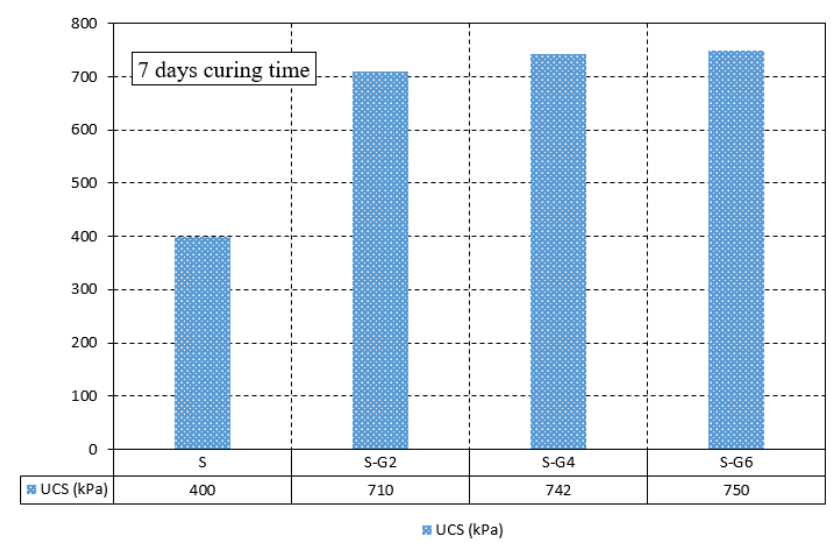

Fig. 3. Effect of glass powder addition on UCS value after 7days curing time.

As can be seen the trend shows increment by increasing glass percentages for 7 days curing time.

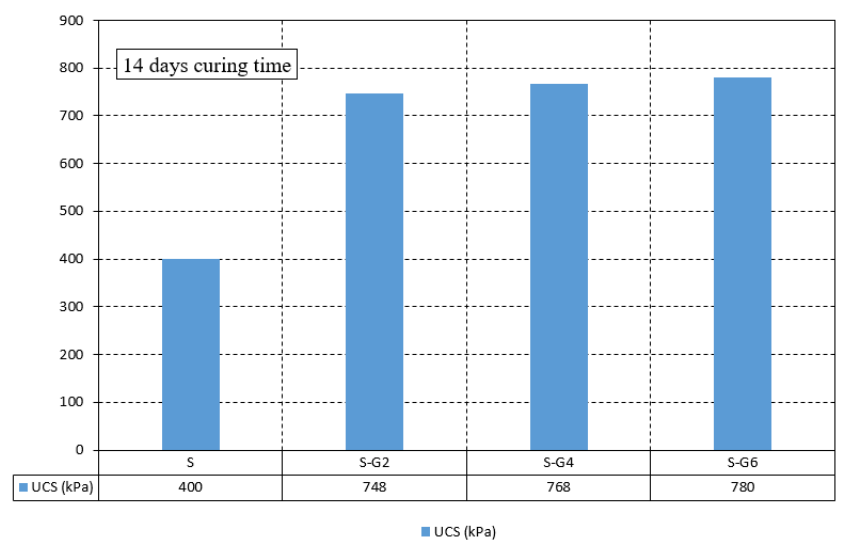

Fig. 4. Effect of glass powder addition on UCS value after 14days curing time.

As can be seen the trend shows increment by increasing glass percentages for 14 days curing.

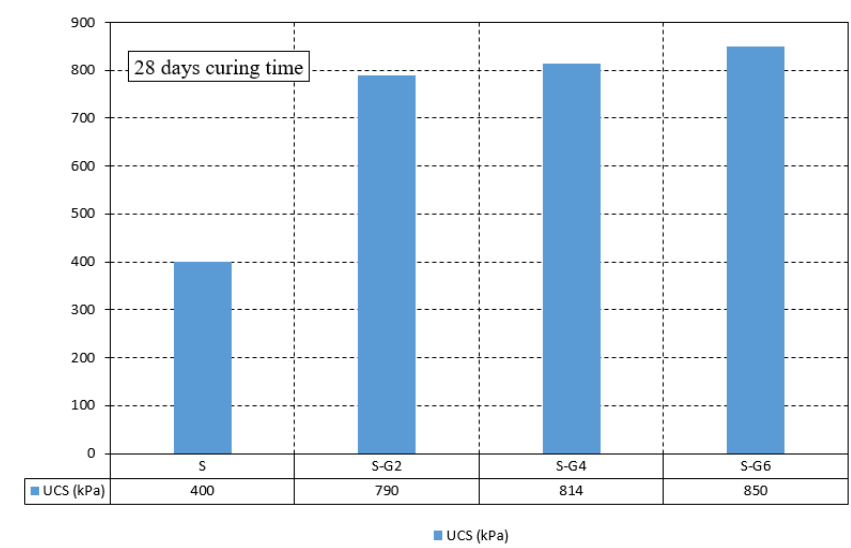

Fig. 5. Effect of glass powder addition on UCS value after 28days curing time.

As can be seen the trend shows increment by increasing glass percentages for 28 days curing.

\section{CONCLUSION}

As the analysis showed addition of glass powder in soil improves the UCS value of the cemented sand. Addition of glass powder shown effective in increasing the OMC and reducing the MDD.

\section{REFERENCE}

[1] Chegenizadeh, A., Nikraz, H. (2011a). "Investigation on strength of fiber reinforced clay" Advanced Materials Research 261-263, pp. 957-963.

[2] Chegenizadeh, A. and H. Nikraz, (2011b). "Study on modulus of elasticity of reinforced clay" - Advanced Materials Research. 243-249: pp. 5885-5889, 2011.

[3] Chegenizadeh, A. and H. Nikraz, (2011c). Composite Soil: Fiber Inclusion and Strength, Journal of Advanced Materials Research 1646

[4] Chegenizadeh, A. and H. Nikraz, (2012). Composite Clayey Sand and Short Fiber, Advanced Materials Research 383, 2764-2769

[5] Chegenizadeh, A., Keramatikerman, M., \& Nikraz, H. (2018b). Liquefaction resistance of fibre reinforced lowplasticity silt. Soil Dynamics and Earthquake Engineering, 104, 372-377.

[6] Al-Rkaby AHJ, Chegenizadeh A, Nikraz H. (2017). Anisotropic strength of large scale geogrid-reinforced sand:experimental study Soils and foundations 57 (4), 557-574

[7] Chegenizadeh A, Keramatikerman M, Panizza S, Nikraz H. (2017). Effect of powdered recycled tire on sulfate resistance of cemented clay. Journal of Materials in Civil Engineering. 2017 Oct 1;29(10):04017160.

[8] Chegenizadeh, A., Keramatikerman, M., Dalla Santa, G., \& Nikraz, H. (2018a). Influence of recycled tyre 
amendment on the mechanical behaviour of soilbentonite cut-off walls. Journal of cleaner production, 177, 507-515.

[9] Mikhail, M., Chegenizadeh, A., Keramatikerman, M., Burns, G., Terzaghi, S., Nikraz, H. (2020). Application of Cane Ash on Compressive Strength of Soil Uncovered to $\mathrm{MgSO}_{4}$. International Journal of Engineering and Advanced Technology (IJEAT) 9(4).

[10] Amiralian S, Chegenizadeh A, Nikraz H (2012a) Laboratory investigation on the compaction properties of lime and fly ash composite, Proceedings of the International Conference on Civil and Architectural applications (ICCAA'2012) 79-83

[11] Amiralian S, Chegenizadeh A, Nikraz H (2012b) Laboratory investigation on the effect of lime on compressibility of soil, Proceedings of the International Conference on Civil and Architectural applications (ICCAA'2012) 89-93

[12] Keramatikerman, M., Chegenizadeh, A., Yilmaz, Y., \& Nikraz, H. (2018b). Effect of Lime Treatment on Static Liquefaction Behavior of Sand-Bentonite Mixtures. Journal of Materials in Civil Engineering, 30(11), 06018017.

[13] Keramatikerman, M., Chegenizadeh, A., \& Nikraz, H. (2018). Effect of Flyash on Post-Cyclic Behavior of Sand. Journal of Earthquake Engineering, 1-13.

[14] Keramatikerman, M., Chegenizadeh, A., Nikraz, H., \& Sabbar, A. S. (2018a). Effect of flyash on liquefaction behaviour of sand-bentonite mixture. Soils and foundations, 58(5), 1288-1296.

[15] Wang, Z., Shi, C., \& Song, J. (2009). Effect of glass powder on chloride ion transport and alkali-aggregate reaction expansion of lightweight aggregate concrete. Journal of Wuhan University of TechnologyMater. Sci. Ed., 24(2), 312-317.

[16] Keramatikerman M, Chegenizadeh A, Nikraz H. (2017b). Experimental study on effect of flyash on liquefaction resistance of sand Soil Dynamics and Earthquake Engineering 93, 1-6

[17] Chegenizadeh, A., \& Keramatikerman, M. (2017). Mitigating sulphate attacks in geotechnical engineering Hauppauge, New York, USA Nova Science Publishers. (pp. 1-165).

[18] Chegenizadeh, A., Keramatikerman, M., Miceli, S., Nikraz, H., Salih Sabbar, A. (2020). Investigation on Recycled Sawdust in Controlling Sulphate Attack in Cemented Clay. Appl. Sci., 10, 1441.

[19] Keramatikerman, M., Chegenizadeh, A., \& Nikraz, H. (2017c). An investigation into effect of sawdust treatment on permeability and compressibility of soilbentonite slurry cut-off wall. Journal of Cleaner Production, 162, 1-6.

[20] Harbi R, Derabla R, Nafa Z. Improvement of the properties of a mortar with $5 \%$ of kaolin fillers in sand combined with metakaolin, brick waste and glass powder in cement. Construction and Building Materials. 2017 Oct 15;152:632-41.

[21] Keramatikerman M, Chegenizadeh A, Nikraz H. STRENGTH OF CEMENTED FLY ASH SOIL. International Journal of Engineering Applied Sciences and Technology (IJEAST), 2020 (accepted).

[22] Du H, Tan KH. Properties of high volume glass powder concrete. Cement and Concrete Composites. 2017 Jan $1 ; 75: 22-9$.

[23] Keramatikerman M, Chegenizadeh A, Terzaghi S. (2019) Review on Effect of Sugarcane Bagasse Ash as an Additive in Construction Industry. 2019. EJGE. Vol.24 Bun. 02.

[24] Elaqra H, Rustom R. Effect of using glass powder as cement replacement on rheological and mechanical properties of cement paste. Construction and Building Materials. 2018 Aug 10;179:326-35.

[25] Chegenizadeh, A., Keramatikerman, M., \& Nikraz, H. (2016). Flexible pavement modelling using Kenlayer. EJGE, 21, 2467-2479.

[26] Chen Z, Poon CS. Comparing the use of sewage sludge ash and glass powder in cement mortars. Environmental technology. 2017 Jun 3;38(11):1390-8.

[27] Keramatikerman, M., Chegenizadeh, A., \& Pu, H. (2017a). Effect of atrazine contamination on compressibility and permeability characteristics of clay. Geotechnical Testing Journal, 40(6), 936-950.

[28] Monawar T, inventor; Zstone Tech LLC, assignee. Cementitious composition containing glass powder as a pozzolan. United States patent application US 10/272,132. 2003 Mar 6.

[29] Keramatikerman M, Chegenizadeh A, Nikraz H. EFFECT OF BENTONITE DOSAGE ON SHEAR BEHAVIOUR OF SAND-FLY ASH. International Journal of Engineering Applied Sciences and Technology (IJEAST), 2020 (accepted).

[30] Al-Rkaby AHJ, Chegenizadeh A, Nikraz H. (2016). Directional-dependence in the mechanical characteristics of sand: A Review International Journal of Geotechnical Engineering 10 (5), 499-509

[31] Pereira-de-Oliveira LA, Castro-Gomes JP, Santos PM. The potential pozzolanic activity of glass and red-clay ceramic waste as cement mortars components. Construction and Building Materials. 2012 Jun 1;31:197203.

[32] Chegenizadeh, A., Keramatikerman, M., Nikraz, H., Importance of Microstructural Analysis in Experimental Soil Stabilization. Global Journal of Engineering Science. 4(5): 2020.

[33] Aly M, Hashmi MS, Olabi AG, Messeiry M, Hussain AI, Abadir EF. Effect of nano-clay and waste glass powder on the properties of flax fibre reinforced mortar. matrix. 2006;2:3. 


\section{International Journal of Engineering Applied Sciences and Technology, 2020 \\ Vol. 4, Issue 11, ISSN No. 2455-2143, Pages 339-342 \\ Published Online March 2020 in IJEAST (http://www.ijeast.com)}

[34] Chegenizadeh A, Aashish M, Nikraz H, Keramatikerman M. Sulphate Attack on Cemented-Bentonite-Coconut Coir. Results in Engineering. 2020 Mar 3:100111.

[35] Olufowobi J, Ogundoju A, Michael B, Aderinlewo O. Clay soil stabilisation using powdered glass. Journal of Engineering Science and Technology. 2014 Oct;9(5):541-58.

[36] Keramatikerman M, Chegenizadeh A, Nikraz H. Effect of Slag on Restoration Mechanical Characteristics of Ethanol Gasoline-Contaminated Clay. Journal of Environmental Engineering. 2018 Jul 1;144(7):06018001.

[37] Khatib JM, Negim EM, Sohl HS, Chileshe N. Glass powder utilisation in concrete production. European Journal of Applied Sciences. 2012;4(4):173-6.

[38] Keramatikerman M, Chegenizadeh A, Nikraz H. Shear strength characteristics of over-consolidated clay treated with ggbfs. Australian Geomechanics Journal. 2018;53(2):141-9.

[39] Moesgaard M, Herfort D, Steenberg M, Kirkegaard LF, Yue Y. Physical performances of blended cements containing calcium aluminosilicate glass powder and limestone. Cement and Concrete Research. 2011 Mar $1 ; 41(3): 359-64$.

[40] Keramatikerman, M. (2018). Investigations into Effect of By-product Binders in Improvement of Cyclic Behaviour of Soil (Doctoral dissertation, Curtin University).

[41] Güllü H, Canakci H, Al Zangana IF. Use of cement based grout with glass powder for deep mixing. Construction and Building Materials. 2017 Apr 15;137:12-20.

[42] Keramatikerman, M., Chegenizadeh, A., Nikraz, H. How Ground Improvement Addresses the United Nation Sustainable Development Goals: A Review. Current Trends in Civil \& Structural Engineering 5(3): 2020. CTCSE.MS.ID.000613.

DOI: 10.33552/CTCSE.2020.05.000613

[43] Mikhail, M., Keramatikerman, M., Chegenizadeh, A., Terzaghi, S., Burns, G., Nikraz, H. (2020). Influence of Bagasse Ash on Compaction Behvaiour of Soil. International Journal of Innovative Technology and Exploring Engineering (IJITEE). 9(5).

[44] Aly M, Hashmi MS, Olabi AG, Messeiry M, Hussain AI. Effect of nano clay particles on mechanical, thermal and physical behaviours of waste-glass cement mortars. Materials Science and Engineering: A. 2011 Oct 15;528(27):7991-8.

[45] Keramatikerman M, Chegenizadeh A, Nikraz H. Effect of sawdust on Cohesion of Sand-Sawdust mixture. International Journal of Engineering Applied Sciences and Technology (IJEAST), 2020 (accepted). 